\title{
Effect of Staff Training on Service Delivery at Kenya Revenue Authority in North Rift Region

\author{
Betty Cherop Kiboss ${ }^{1 *}$, Dr. Geoffrey Kiptum Kimutai, Ph.D ${ }^{2}$
}

${ }^{1}$ Master of Business Administration Degree (Strategic Management Option), Kenya

${ }^{2}$ Lecturer, Jomo Kenyatta University of Agriculture and Technology, Kenya

DOI: $10.36347 /$ sjebm.2020.v07i11.002

| Received: 04.11.2020 | Accepted: 13.11.2020 | Published: 19.11.2020

*Corresponding author: Betty Cherop Kiboss

\section{Abstract}

Original Research Article

Currently, taxpayers have been struggling to file their tax returns, make payments, process refunds and be tax compliant. This has seen more traders coming up with new ways to evade paying taxes, and the tax gap in Kenya has been estimated at over $40 \%$. The study's main purpose is to determine the effect of staff training on service delivery at Kenya Revenue Authority in the North Rift Region. The guiding objective of the study is to determine the effect of staff training on service delivery at Kenya Revenue Authority. This study adopted the Theory of Reinforcement relevant to staff training on service delivery at the Kenya Revenue Authority. This study adopted a cross-sectional research design. The target population for this study was the Kenya Revenue Authority. The accessible population was 430 comprising of customer service advisers, tier officers, chief managers, IT officers, customs officers, and clients from the 3 KRA stations selected from North Rift Region (Eldoret, Lodwar, and Kitale) because the researcher can get the study information's concerning the effect of staff training on service delivery at Kenya Revenue Authority. The sample size of the study was 207 respondents. The study used a structured questionnaire to collect the required information from the respondents. A pilot test was carried out in KRA stations in South Rift Region. The analysis estimated the coefficients of this predictive linear equation involving more than one of the independent variables. The variable must pass the tolerance criteria at a significance level of 0.05 . The study findings were used to make conclusions and recommendations on staff training on service delivery at the Kenya Revenue Authority. The study findings revealed a staff training positively and significantly affects service delivery at the Kenya Revenue Authority $(\beta=.460, p=0.000)$. The study concluded that frequent staff training has reduced tax error problems because employees understand better operational terms, which has improved service delivery. The study recommends that the Kenya Revenue Authority focus on training personnel to operate on the efficiently I tax systems.

Keywords: Staff training, service delivery, Kenya revenue authority, effect, north rift region.

Copyright ( 12020 The Author(s): This is an open-access article distributed under the terms of the Creative Commons Attribution 4.0 International License (CC BY-NC 4.0) which permits unrestricted use, distribution, and reproduction in any medium for non-commercial use provided the original author and source are credited.

\section{BACKGROUND TO THE STUDY}

The continuous improvement model relies greatly on employees, not only top management, to identify opportunities for improvement. This bottom-up improvement is effective because employees are closest to the problems, and thus better equipped to solve them. Staff training is the process of training the current staff of the organization for enhancing the performance of the staff as well as the productivity of the organization. One important aspect of the business is training the staffs as they are one of the valuable assets. It is mandatory to train the staffs with the skill and knowledge required to meet the business objectives [1].

It is the process of keeping the employees aligned with the organization's values and work ethics and to actively getting them involved to achieve organizational goals and objectives. Involving the employees usually gives them more autonomy for better performances and thereby, helping them to reach their full potential. Achieving full potential was meant that your employees would eventually love to work for you [2]. Client's feedback is the information, insights, issues, and input shared by your community about their experiences with your company, product, or services. This feedback guides improvements of the customer experience and can empower positive change in any business even (and especially) when it's negative. Customer feedback is important because it serves as a guiding resource for the growth of your company [3].

Despite the importance of public services delivery, there are large differences in delivery across the world. On this issue, the World Development Report [4] has most prominently highlighted the large 
variation in both quality and quantity across a wide range of developing countries, pointing to challenges policy makers and frontline providers face. The report painted a grim picture of the state of public services, stating that "social services fail for the poor. This was done paying particular attention to evidence and lessons for Asia revenue collection authority.

\section{Statement of Problem}

An effective and efficient program of taxpayer service activities is a critical objective of all revenue bodies [5]. The general complexity of tax laws coupled with the relatively large populations of taxpayers to be administered mean that all revenue bodies must rely substantially on taxpayers' voluntary compliance to achieve the outcomes expected of them. It is axiomatic that to achieve high levels of voluntary compliance, taxpayers and their representatives must have a good standard of services to help them determine their obligations under the laws and to complete the steps required to acquit those obligations [5]. The physical appearance of equipment, facilities and layout should facilitate taxpayers' services [6]. However, currently taxpayers have encountered challenges in pursuing tax compliance that had let to more traders and businesses are coming up with new ways to evade paying taxes and tax gap in Kenya has been estimated at over 40\% [7]. This has been largely hampered by possible delays and poor service delivery. Currently, taxpayers in north rift region and Kenya at large have to wait for payment receipts for almost a month to ascertain that their payment was received by the KRA. Also, there is a large informal sector in Kenya that is not within the tax net, yet all must contribute to raising the resources to finance government expenditure and thus ensure equity in taxation. The members of public also have poor awareness of the tax laws [8]. The indirect taxes impost by the KRA to the public negatively influences the economic growth in Kenya in the short run. It implies that indirect taxes increase consumption and reduce savings in Kenya. In long run the poor service delivery at KRA has raised the investment cost and accordingly lowering the return on investment with regard to taxation of the invested activity whereby income taxes create a deterrent to earning taxable income. As they exchange activities with lower taxation rate with the ones having higher taxation rate, the tax payers eventually focused in less productive activity within an economy [9]. The research that existed focused on services delivery in tax collection authorities in Africa and especially Kenya. Additionally, few studies have explored staff training as a predictor of service delivery.

\section{Research Objective}

The study was guided by the following research objective:

To determine the effect of staff training on service delivery at Kenya Revenue Authority in north rift region.

\section{Research Hypotheses}

$\mathbf{H}_{01}$ : Staff Training does not have a statistically significant effect on service delivery at Kenya Revenue Authority in north rift region.

\section{LITERATURE REVIEW}

This section covers theoretical review, empirical review and conceptual framework.

\section{Theory of Reinforcement}

Reinforcement Theory was proposed by Skinner [10]. It is based on the concept of "Law of Effect", for examples, the behavior of individual towards positive consequences tends to repeat, but the behavior of individual towards negative consequences tends not to repeat. This theory emphasizes on the learning behavior of a person and suggests that the learner repeated that behavior which is attached with a positive outcome or result. Skinner an economist of behaviorist school of thought proposed the theory of reinforcement and suggested that the training and development programs should be aligned with the organizational objectives and a positive outcome should be expected with such training and development programs.

The main assumption that guides this theory is that people do not like to be wrong and often feel uncomfortable when their beliefs are challenged. Reinforcement theory is relevant to the study because it is evident that managers need to motivate employees to obtain the desirable results for the organization. There is consensus about the facts that motivation is an individual phenomenon. It is described as being intentional and multifaceted and that the purpose of Reinforcement theories is to predict behavior. Irrespective of the industry within which an organization operates, the concept of motivation cannot be looked down upon [11]. Reinforcement Theory is relevant to the study as its aims at achieving the desired level of motivation among the employees by means of reinforcement through staff training. Reinforcement approach, which can be both positive and negative, is used to reinforce the desired behavior.

\section{Staff Training and Service Delivery}

A study in Canada by Levine [12] showed that training is a necessity in the workplace. Without it, employees don't have a firm grasp on their responsibilities or duties. Employee training refers to programs that provide workers with information, new skills, or professional development opportunities. Effective training and development programs are aimed at improving the employees' performance. Training could be given through different methods such as on the coaching and mentoring, peers cooperation and participation by the subordinates. This team work enables employees to actively participate on the job and produces better performance, hence improving organizational performance. Nevertheless, the study 
was done in Canada and other study need be done in Kenya.

Bryson [13] deduced that training programs not only develops employees but also help an organization to make best use of their humane resources in favor of gaining competitive advantage. Therefore, it seems mandatory that firms should plan for such training programs for its employees to enhance their abilities and competencies according to the demands of the workplace. Training develops the capabilities of the employee but sharpen their thinking ability and creativity in order to take better decision in time and in more productive manner. Training develops selfefficacy and results in superior performance on job, by replacing the traditional weak practices by efficient and effective work-related practices. Nevertheless, the study focused on training employee but also make best use of human resource as compared to my study it majored on training employee on service delivery.
Oviawe [14], suggest that training may also be an efficient tool for improving one's job satisfaction, as employee better performance leads to appreciation by the top management, hence an employee feels more adjusted with his job. Trained employees are more able to satisfy the customers and, employees who learn as a result of training program shows a greater level of job satisfaction along with superior performance. Training refers to a planned intervention aimed at enhancing the elements of individual job performance". But collecting customer feedback is just the first step to ensuring a successful customer experience. It's what the institution does with the feedback that truly matters. Nevertheless, the study majored training on improving job satisfaction as compared to my study objective training on service delivery.

\section{Conceptual Framework}

The study was based on a conceptual framework showing the relationship between the independent and dependent variables.

\begin{tabular}{|c|c|}
\hline Staff Training & Service Delivery \\
\hline$\checkmark$ Tax error & $\checkmark \quad$ Resnonsiveness \\
\hline$\checkmark$ Itax enhancement & $\checkmark$ Reliability \\
\hline$\checkmark$ Customer service & $\checkmark$ Empathy \\
\hline$\checkmark$ Tax Laws & $\checkmark$ Assurance \\
\hline$\checkmark$ Emerging issues & $\checkmark$ Tangibles \\
\hline Independent Variables & Dependent Variable \\
\hline
\end{tabular}

Fig-1: Conceptual Framework

\section{RESEARCH METHODOLOGY}

This area covered research design, target population, sample size and sampling procedures, research instrument, pilot study, data analysis and presentation.

\section{Research Design}

This study adopted a cross-sectional research design. In this study the design helped in examining the effect of staff training on service delivery at Kenya Revenue Authority as they exist in a defined population at a single point in time and over a short period of time [15].

\section{Target Population}

The target population for this study was Kenya Revenue Authority. The accessible population was 430 comprising of customer service advisers, tier 1 officers, chief managers, IT officers, custom officers and clients from the 3 KRA stations selected from North Rift Region (Eldoret, Lodwar and Kitale) because currently, taxpayers in north rift region are complaining of delays in payment receipts for almost a month to ascertain that their payment was received by the KRA.

\section{Sample Size and Sampling Procedures}

The researcher adopted stratified and proportionate sampling technique to select respondent to take part in the study.

The researcher obtained sample size using Yamane formulae [16].

$$
n=\frac{N}{1+N(e)^{2}}
$$

Equation 1

Where,

$\mathrm{n}$ is the sample size required

$\mathrm{N}$ is the population size $=430$

$\mathrm{e}$ is the level of precision $=0.05$

$\mathrm{n}=430 /\left(1+430 * 0.05^{2}\right)$

$\mathrm{n}=207$ respondents

Therefore, the sample size for the study was 207 and respondent was proportionally distributed 


\section{Research Instruments}

The study used structured questionnaire to collect the required information from the respondents. Questionnaires are preferred because they are easy to administer and are cost and time effective. The questions were structured in a five -point likert scale. These questions allowed participants to rank their agreement as: strongly agree, agree undecided, disagree and strongly disagree.

\section{Pilot Test}

Pilot test was carried out in KRA stations in South Rift Region that was not be involved in the main study, in order to ascertain validity and reliability of the research instruments. The researcher was administering 21 questionnaires to respondents representing $10 \%$ of sample size [17].

\section{Data Processing and Analysis}

The study applied descriptive and inferential statistics to analyze collected data with the aid of SPSS software. Descriptive statistics included frequency, means, variance and standard deviation. Inferential statistics was correlation and multiple regressions. All variables must pass the tolerance criteria at a significance level of 0.05 . The following multiple regression models shall be adopted.

$\mathrm{Y}=\beta_{0}+\beta_{1} \mathrm{X}_{1}+\varepsilon \ldots \ldots \ldots \ldots \ldots \ldots \ldots \ldots$ Equation 2

Where:

Y Represents service delivery at Kenya
Revenue Authority
$\boldsymbol{\beta}_{\mathbf{0}}$ Represents constant
$\mathbf{X}_{\mathbf{1}}$ Represents staff training

\section{$\boldsymbol{\varepsilon}$ Represents Error Term}

$\boldsymbol{\beta}_{1}$, repesent régression coefficients of the Independent variables.

\section{RESEARCH FINDINGS AND DISCUSSIONS}

This section presents data analysis results, interpretations and discussions.

\section{Response Rate}

The researcher administered 207 questionnaires to employees at Kenya Revenue Authority North Rift Region. The response rate results are presented in Table-1.

Table-1: Response Rate

\begin{tabular}{|l|l|l|}
\hline Response Rate & Populatio & Percentag \\
\hline Questionnaire distributed & 207 & 100 \\
\hline Correctly filled and & 181 & 87.4 \\
\hline Non response & 26 & 12.6 \\
\hline
\end{tabular}

Table-1 revealed that out of 207 distributed questionnaires, 181 were correctly filled and returned representing $87.4 \%$ response rate. This high response rate of $87.4 \%$ was attributed by the researchers follow up on filling of questionnaires and explaining to the respondents where they couldn't understand.

\section{Effect of Staff Training on Service Delivery}

The second objective of the study was to determine effect of staff training on service delivery at Kenya Revenue Authority in north rift region. The study findings are presented in Table-2.

Table-2: Staff Training and Service Delivery

\begin{tabular}{|l|l|l|l|l|l|l|l|l|}
\hline Statements & & SA & A & UD & D & SD & Mean & Std. \\
Dev
\end{tabular}

The study findings in Table- 2 revealed that $150(82.9 \%)$ of the respondents agreed with the statement that frequent training of personnel by Kenya Revenue Authority has reduced tax error problems because employees understand better operational terms. Also, 9(5\%) of the respondents disagreed with the statement that frequent training of personnel by Kenya Revenue Authority has reduced tax error problems because employees understand better operational terms. In terms of mean and standard deviation majority of the respondents agreed with the statement that frequent training of personnel by Kenya Revenue Authority has reduced tax error problems because employees understand better operational terms (mean $=4.12$, standard deviation=0.89). Also $98(54.2 \%)$ of the respondents agreed with the statement that Itax system is efficiently operated because personnel have been trained on how to use it for the purpose of efficiency. Further, 18(9.9\%) of the respondents disagreed with the statement that itax system is efficiently operated 
because personnel have been trained on how to use it for the purpose of efficiency.

In terms of mean and standard deviation majority of the respondents agreed with the state that Itax system is efficiently operated because personnel have been trained on how to use it for the purpose of efficiency $\quad($ mean=3.77, standard deviation=1.08). Further, 140(77.4\%) of the respondents agreed with the statement that there is improved customer service due to employees training sessions on customer's experience. Also, 13(7.2\%) of the respondents disagreed with the statement that there is improved customer service due to employees training sessions on customer's experience. In terms of mean and standard deviation majority of the respondents agreed with the statement that there is improved customer service due to employees training sessions on customer's experience (mean=4.06, standard deviation $=1.09$ )
Lastly, 181(72.4\%) of the respondents agreed with the statement that all the workers understand the tax laws and emerging issues within the organization thus improving delivery of services. Further, 31(17.2\%) of the respondents disagreed with the statement that all the workers understand the tax laws and emerging issues within the organization thus improving delivery of services. In terms of mean and standard deviation majority of the respondents agreed with the statement that all the workers understand the tax laws and emerging issues within the organization thus improving delivery of services (mean=3.76, standard deviation=1.11).

\section{Correlation Analysis}

Pearson correlation analysis was carried out to show the strength and direction of the association between total quality management and service delivery at Kenya Revenue Authority in North Rift Region. Table-3 present the results.

Table-3: Correlation Analysis

\begin{tabular}{|l|l|l|l|l|}
\hline Variables & Service delivery & & Staff training \\
\hline \multirow{2}{*}{ Service delivery } & Pearson Correlation & 1 & & \\
\cline { 2 - 5 } & Sig. & & & \\
\hline \multirow{2}{*}{ Staff training } & Pearson Correlation & $.892^{* *}$ & $.439^{* *}$ & 1 \\
\cline { 2 - 5 } & Sig. & .000 & .000 & \\
\hline
\end{tabular}

The study findings in Table-3 indicated a strong, positive and statistically significant correlation between staff training and service delivery $(r=0$. 892; $\mathrm{p}<0.01)$.

\section{Results for Multiple Regression Analysis}

Multiple regression analysis was run to establish the effect of staff training on service delivery at Kenya Revenue Authority in North Rift Region.

Table-4: Regression Model Coefficients

\begin{tabular}{|l|l|l|l|l|l|}
\hline \multirow{2}{*}{} & \multicolumn{2}{|l|}{ Unstandardized Coefficients } & Standardized Coefficients & t & \multirow{2}{*}{ Sig. } \\
\cline { 2 - 6 } & B & Std. Error & Beta & & \\
\hline (Constant) & .352 & .130 & & 2.703 & .008 \\
\hline Staff training & .460 & .086 & .471 & 5.352 & .000 \\
\hline $\mathrm{R}^{2}$ & .833 & & & & \\
\hline F-statistic & $218.82 * * *$ & & & & \\
\hline
\end{tabular}

The $\mathrm{R}^{2}$ indicates that explanatory power of the independent variables was 0.833 . This implied that about $83.3 \%$ of the variation in service delivery at Kenya Revenue Authority is explained by the regression model. Table-4 showed that the employee's F-statistics produced $(\mathrm{F}=218.8)$ which was significant at $\mathrm{p}=0.000$ thus confirming the fitness of the model. This implies that the multiple regression model was good fit for the data. Hence staff training affects service delivery at Kenya Revenue Authority in North Rift Region. The $\mathrm{F}$ value indicates that all the variables in the equation are important hence the overall regression is significant.

The study results in Table- 4 revealed that staff training has a positive and significant effect on service delivery at Kenya Revenue Authority $(\beta=.460$, $\mathrm{p}=0.000)$. This implies that an increase in staff training leads to increase in service delivery at Kenya Revenue Authority by 0.460 units. Thus, the regression equation becomes;

$\mathrm{Y}=0.352+0.460 \mathrm{X}_{1}$ Equation 3

\section{Hypotheses Testing}

The regression results indicated that staff training have a statistically significant effect on service delivery at Kenya Revenue Authority in north rift region $\left(\beta_{2}=.460, \mathrm{p}<0.05\right)$. Therefore, the study rejected the null hypothesis $\mathrm{H}_{01}$ : that staff training does not have a statistically significant effect on service delivery at Kenya Revenue Authority in north rift region and concluded that staff training statistically has significant effect on service delivery. 


\section{SUMMARY OF FINDINGS, CONCLUSIONS AND RECOMMENDATIONS}

This section summarizes the findings and makes conclusions and recommendations.

\section{Summary of the Findings \\ The second study objective sought to} determine the effect of staff training on service delivery. The study found out that the respondents agreed on all of the all aspects of staff training. The study rejected the null hypothesis that staff training does not have a statistically significant effect on service delivery at Kenya Revenue Authority in north rift region. They agreed that frequent training of personnel has reduced tax error problems because employees understand better operational terms, Itax system is efficiently operated because personnel have been trained on how to use it for the purpose of efficiency, there is improved customer service due to employees training sessions on customers experience and all the workers understand the tax laws and emerging issues within the organization thus improving delivery of services.

\section{Conclusions of the Study}

The study also concluded that staff training has a positive influence on service delivery at Kenya Revenue Authority in north rift region. The findings of the study indicate a strong, positive and statistically significant correlation between staff training and service delivery the study also, Frequent training of personnel has reduced tax error problems because employees understand better operational terms and this has improved on service delivery. There is improved customer service due to employees training sessions on customers experience.

\section{Recommendations of the Study}

The study recommends that Kenya Revenue Authority should focus on training personnel to efficiently operate on the I tax systems.

\section{REFERENCES}

1. Morsy MA, Ahmed GS, Ali NA. Impact of Effective Training on Employee Performance in Hotel Establishments. International Journal of Heritage, Tourism, And Hospitality, 2016;10(2), 23-79.

2. Kim M, Beehr TA. Self-Efficacy and Psychological Ownership Mediate the Effects of Empowering Leadership on Both Good and Bad Employee Behaviors. Journal of Leadership \& Organizational Studies, 2017;24(4), 466-478.

3. Perlman SG, Van Der Laan R, Cotter T, Furman S, Mccool R, Buckley I. U.S. Patent No. 9,314,691. Washington, DC: U.S. Patent and Trademark Office. 2016.
4. World Bank. Map Design Unit. World Bank Atlas. World Bank Publications. 2004.

5. Martinez-Fernandez C, Martinez-Fernandez C, Kubo N, Noya A, Weyman T. Demographic change and local development: shrinkage, regeneration and social dynamics. Paris: OECD publishing; 2012.

6. Eissa NO, Jack W, Gordon RH. Tax Reform in Kenya: Policy and Administrative Issues. Taxation in Developing Countries: Six Case Studies and Policy Implications, 2010;7(6), 198-210.

7. Mawia, M., \& Nzomoi, J. (2013). An Empirical Investigation of Tax Buoyancy in Kenya. African Journal of Business Management, 7(40), 42334246.

8. Zia ur Rehman M, Waris A, Gilani SO, Jochumsen M, Niazi IK, Jamil M, Farina D, Kamavuako EN. Multiday EMG-based classification of hand motions with deep learning techniques. Sensors. 2018 Aug;18(8):2497.

9. Onduru D, Muchena FN, Gachimbi LN, de Jager A. Farmer Field School on Nutrient Management. LEISA: ILEIA newsletter for low-external-input and sustainable agriculture. 2003;19(4):26-7.

10. Skinner DJ. Earnings disclosures and stockholder lawsuits. Journal of accounting and economics. 1997 Nov 1;23(3):249-82.

11. Jibowo AA. Effect of Motivators and hygiene factors on job performance among extension workers in the former Western state of Nigeria. The Quarterly Journal of Administration, 12 (1). 2007:45-54.

12. Levine DI. Working in the 21st Century: Policies for Economic Growth Through Training, Opportunity and Education: Policies for Economic Growth Through Training, Opportunity and Education. Abingdon: Routledge. 2016.

13. Bryson JM. Strategic Planning for Public and Nonprofit Organizations: A Guide to Strengthening and Sustaining Organizational Achievement. New Jersey: John Wiley \& Sons. 2018.

14. Oviawe JI. Revamping Technical Vocational Education and Training Through Public-Private Partnerships for Skill Development. Makerere Journal of Higher Education, 2018;10(1), 73-91.

15. Kratochwill TR., Hitchcock JH, Horner RH, Levin JR, Odom SL, Rindskopf DM, Shadish WR. Single-Case Intervention Research Design Standards. Remedial and Special Education, 2013;34(1), 26-38.

16. Yamane T. Elementary sampling theory. 1967.

17. Browne S. Optimal investment policies for a firm with a random risk process: exponential utility and minimizing the probability of ruin. Mathematics of operations research. 1995 Nov;20(4):937-58. 